\title{
Political Strategies for Winning Female Figuresin the Village Head Election Contestationin Lauran Village
}

\author{
V Watunglawar ${ }^{1}, \mathbf{R}$ Rahardian $^{2}$ \\ ${ }^{1,2}$ Master's Program in Public Policy, Faculty of Social Science and Political Science, Universitas \\ Airlangga, Surabaya. \\ 1watunglawarvinsen@gmail.com,2 2 ramaditya.rahardian-2018@fisip.unair.ac.id
}

\begin{abstract}
The objective of this study was to uncover the political strategy done by a female candidate so as to win the Village Head Election Contestation in Lauran Village. By using qualitative methods, the researchers conducted in-depth interviews with 20 informants including Maria FaniMasela as the elected village head candidate and several members of the winning team. The results show that the election of Maria FaniMasela as the head of the Lauran Village in the 2014-2020 period was due to the strengthening of the community's enthusiasm for the offer of Vision, Mission, and work program both in the field of community empowerment and infrastructure development that were deemed relevant to the community needs. This enthusiasm was then used by the winning team by visiting residents' houses to ask for political support. This movement was further strengthened by the Women's Concerned Democracy Group (KPPD) which actively mobilized the masses, especially female voters, to support Maria Fani Masela.
\end{abstract}

Keywords: Contentation, Female Candidate, Political Strategy.

\section{INTRODUCTION}

The election of village heads in the last decade has led to rare phenomena such as the presence of female candidates in political contestation. This scarcity is a result of the dominance of patriarchal culture which is still quite strong in Indonesian politics where men always dominate women because women are always perceived to be second after men, both in terms of division of work and decisionmaking (Fox, Richard L and Lawless, 2011). Despite the reality, the courage of Maria FaniMasela as a female candidate to participate in the election of Lauran Village head can change public perception of the importance of gender equality because of 83 villages in West Southeast Maluku District, only Lauran Village as the only village that had female candidates elected as the village head in the 2014-2020 period. This victory further strengthens the principle in the theory of liberal feminism which assumes that both women and men can think rationally, so that they should have the same rights and opportunities to advance themselves, especially in the political sphere.

The election of Maria FaniMasela as the head of Lauran Village is inseparable from her ability to formulate and implement political strategies effectively. It is because according to Firmanzah (2008: 10), a strategy is a vital component to achieve a goal, both related to aspects of 
the resources sacrificed and their effect on the achievement.Therefore, this study not only discusses the involvement of women in the political arena, but more specifically also discusses what political strategies are carried out by women candidates to win the head election contestation of Lauran Village from the perspective of political marketing theory from (Reid, 1988).

\section{RESEARCH METHODS}

This study uses qualitative methods from (Sugiyono, 2012) and descriptive approach (Bogdan \& Taylor, 2012). In addition, data collection techniques prioritized direct data (first hand) obtained through in-depth interviews with 20 informants, including Maria FaniMasela as the elected head candidate for Lauran Village along with several members of the winning team to obtain information related to what political strategies to win the head election contestation of Lauran Village for the 2014-2020 period.The main instrument in this study was the researchers themselves (human instrument), while data analysis in principle used interactive analysis which included: collecting data, selecting data, condensing data, and drawing conclusions following (Miles, M. B., Huberman, A. M., \& Saldaña, 2014).

\section{RESULTS AND DISCUSSION}

Head election of Lauran Village obtained legitimacy through Law Number 32 of 2004 concerning Regional Government, Law Number 6 of 2014 concerning Villages and Regulation of Minister of Domestic Affairs Number 112 of 2014 concerning Election of Village Heads. Substantially, these three regulations govern the simultaneous election of village heads in all districts and cities. The provision is the basis for the establishment of the Regional Regulation of West Southeast Maluku District Number 8 of 2013 concerning Procedures for Nominating and Election of Village Heads.To organize the election of the village head, the regional government formed a district committee whose task was to coordinate, facilitate, supervise, and evaluate the election implementation process in each village.

Technically, the arrangement of the head election of Lauran Village is the responsibility of the Village Consultative Association (BPD). Therefore, the BPD formed a village head election committee whose members are representatives of village officials, community institutions, and community leaders. In carrying out their duties, the committee first conducted a selection of prospective candidates by allowing each custom group (SoaMadedembun, Besembun, Arwalembun, UlmasembunandTaborat) to propose the names of the prospective village head. Of the seven names proposed, then the village level committee submitted the name to the West Southeast Maluku District committee for a feasibility selection. As a result, the prospective candidates who passed the selection process who determined as candidates for Lauran Village head were Maria FaniMasela as a female figure from the Madedembuncustom group and two other village head candidates including Yakobus Fadirsyair from the Taborat custom group and OtovianusAruibulur from the Ulmasembun custom group.Next, the selection committee opened a campaign period (from September 4 to September 6,2013 ), so that the candidates could hold dialogues with the community to convey their vision, mission, and work program. Then, on September 10,2013, a direct village head election was held with a total of 1,200 voters and continued with a vote count process which showed Maria FaniMasela's dominance with 670 votes of support, OktivianusAruibulur received 320 votes and 
YakobusFadirsyair received 210 votes (Report of the election committee of Lauran Village Head, 2014).

The victory of the female candicate to win from the other two village head candidates was obtained with an effort, because during the campange period, Maria FaniMasela succeeded to drive her politic resource the winning team, political strategy and economic capability) to attreact voters' support.Controlling the political influence requires an effective strategy as explained by (Niffenegger, 1989)inFirmanzah (2012: 200-209)who said that a candidate needs to apply a 4P program which consists of products, promotion, price and place during the campaign activity so that the community know the figure better during the campaign activities so that the community will become more aware of the figures and political products offered(Kacung Marijan, 2010). The product explained by (Niffenegger, 1989) is a political product which includes: First, The work program offered by the candidate. The work program offered by Maria FaniMasela is implicitly contained in the Vision "The realization of Lauran Kote that is able to protect, serve, and prosper the community and protect the customs in the life of the indigenous people of Lauran Village" and the Mission, including improving cross-village coordination, law enforcement and optimizing the role of duan lolat, carrying out community service functions in accordance with applicable regulations, encouraging the use of natural resources to increase income and meeting household needs, optimizing the role of custom institutions and BPD to preserve customs in community's lives.

Based on the description of the Vision and Mission, the development priority is on the economic aspect, which is encouraging the use of natural resources to increase income and fulfill household needs. These priority aspects are formulated in three community empowerment programs, including: Empowerment in agriculture, including assistance with lawn mowers, assistance with water pumping alkon machines, fertilizer and pest control drugs, conducting training in management and development of agricultural product production and opening access to revenue sharing agricultural production to be marketed. Then, community empowerment in the field of animal husbandry, including the assistance of cattle, pigs and goats for the community to be maintained. Empowerment in the field of fisheries, including the assistance of rolling machines, boat assistance, fishing net assistance, and opening access to marketing fishing products. In addition, there are also offers for other programs related to infrastructure development such as construction of village fences, construction of footpaths, drainage construction, construction of clean water infrastructure, construction of school buildings for kindergartens and early childhood education (PAUD). While the program in the field of education includes financial assistance for college students who are preparing their final project (Undergraduate thesis, thesis and dissertation). These work programs offered can give a positive image so that the community increasingly trust in the reputation and credibility of Maria FaniMasela as the candidate for the head of Lauran Village.

Second, Notes about things that have been done in the past.In the LauranVillage, Maria FaniMasela was a member of the Family Welfare Development (PKK) organization from 1990 to 2013. Initially, Maria FaniMasela served as a regular member, but because of her abilities, she was elected as PKK secretaryin 2004. In her active period, Maria FaniMasela together with the Lauran Village PKK Team succeeded in implementing several women's empowerment programs, such as entrepreneurship training, handicraft and arts programs, creative economic programs, arranging beauty and environmental cleanliness so that the community could feel the positive impact of these programs.This success makes Maria FaniMasela known as a woman who has leadership qualities 
and is capable when speaking in public so that her figure is very influential and respected by various groups.

In addition, Maria FaniMasela was also active in religious organizations, the Catholic Women's Organization of the Republic of Indonesia (WKRI), starting in 1998 as a regular member and in 2008 she was elected as the chairman so that she assumed the task of leading all WKRI members covering three villages including, Lauran Village, Kabyarat Village, and Ilngei Village. During her leadership from 2008 to 2012, Maria FaniMasela succeeded in making the WKRI organization a driving force for Catholic religious activities such as, joint prayer activities, activities to deepen the Catholic faith, choir activities, activities to equip the family of faith and advocacy activities for the poor and abandoned children. Besides, Maria FaniMasela also succeeded in encouraging the WKRI organization to be involved in every activity of the Government of West Southeast Maluku District, specifically focusing on empowering and educating women.

Third, Personal Characteristics.In addition to having a leadership spirit, Maria FaniMasela is also famous for her caring personality and easy to get along with other people. This track record and characteristics of simplicity become a political capital for Maria FaniMasela to increase public confidence in her capacity.Of the three categories of political products owned by Mari FaniMasela, appropriate promotional strategies are needed so that the community truly understands the political products offered. According to (Wring, 1996), promotional activities need to be carried out through print and electronic media as well as other means of building slogans, jargon and images to be presented. Therefore, Maria FaniMasela and the winning team promoted their political products through distribution of pamphlets and posters containing the Vision, Mission and work program offerings. Furthermore, she managed the winning team in charge of visiting residents' homes to ask for political support as well as the Women's Concerned Democracy Group (KPPD) that make campaign for various achievements and accomplishments of Maria FaniMasela while leading the PKK organization of Lauran Village and the WKRI organization. Besides, the KPPD group also mobilized the community, especially women voters, to support Maria FaniMasela.

In order to make the promotion can have an impact on increasing the amount of mass support, according to (Niffenegger, 1989), a candidate must be strengthened by political prices. The price of political marketing covers many things, from economics, psychology, to the image of candidates in the eyes of the public. In terms of economic price, the costs incurred by Maria FaniMasela during the campaign period was IDR 25,000,000, which were used to procure campaign attributes (pamphlets and posters) and to fund the consumption needs of the winning team. While in the aspect of psychological price, it involves a feeling of comfort from voters regarding the ethnic, religious, educational background, etc. of a candidate (Firmanzah, 2012: 205)In this context, the presence of Maria FaniMasela as a candidate for the head of the Lauran Village received the enthusiasm of the community. It was known that in addition to embracing religion (Catholic) which is the same as the Lauran Village community, Maria FaniMasela is from a family that is quite economically successful and has an important position in the customary order of the Lauran Village. In addition, Maria FaniMasela has a senior high school education, has organizational experience, likes to protect and is easy to get along with. These factors naturally give birth to a comfortable feeling for most community so they tend to give political votes to Maria FaniMasela.

The economic and psychological prices presented to the public can strengthen the image price so that they are able to convince voters of a candidate who is expected to be able to give a positive image and be the pride of all people(Firmanzah, 2012). The existence of Maria FaniMasela as the 
first female figure who nominated herself as the village head opened a new chapter in the political culture of the Lauran Village which was still patriarchal in nature. This nuance gave birth to the hopes of the community of a leader who is motherly, firm, honest, and caring for the suffering of the people.

The effect of promotion of various political products and political prices presented to the public has implications for the introduction of a candidate figure, but Maria FaniMasela and the winning team were not only limited to conducting promotional activities, but also political segmentation through survey activities in order to know the structure and characteristics of voters. The results show that the voters of Lauran Village were divided into several groups based on livelihood categories, including fishing communities by $20 \%$, farming communities by $50 \%$, people who work as Civil Servants (PNS) and professional staff by 10\%, college student groups by $15 \%$ and other professional communities by $5 \%$ (Winning team data, 2013).

Based on these data, the number of voters is identified as permanent supporters (voters who gave political choices to Maria FaniMasela), voters from the uncertain masses (who do not yet have political choices over certain candidates), and voters from mass supporters of other village head candidates. Then, Maria FaniMasela and the winning team conducted a political positioning to place political images and products in accordance with the needs and desires of each target community group. The results of this sorting are used as the basis for developing a political communication strategy. The communication pattern developed by Maria FaniMasela when engaging in dialogue with farmer groups is to offer training programs to increase agricultural production, aid agricultural equipment, and open access to marketing agricultural products. Whereas the superior program offered to the fishing community groups is the assistance of fishing equipment and opening access to marketing the results of fishing (Schroder, 2010)

The same political communication strategy was carried out during a dialogue with college student groups, in which Maria FaniMasela promised that if she is elected as village head, she will provide educational funding for all students from Lauran Village. Whereas for people who work as civil servants and professionals as well as other professions, Maria FaniMasela offered a program of village infrastructure development and clean water management. This strategy according to Niffenegger (1989) relates to Place, which is, the process of distributing political products and the way present contestants to establish communication with voters.Offering programs that fit the needs of the community group could increase their confidence in the figure of Maria FaniMasela so it is not surprising that she received most of the support from Lauran Village community.

\section{CONCLUSIONS}

The results presented show that the victory obtained by Maria FaniMasela resulted from the strengthening of community's enthusiasm for the offer of Vision, Mission, and Work programs in the field of community empowerment and infrastructure development that were considered relevant to the needs of the community. This condition was successfully utilized by the winning team by visiting residents' homes to ask for political support. In addition, the movement of the Women's Concerned Democracy Group (KPPD) to mobilize the mass of supporters, especially female voters, was the most effective strategy in increasing the amount of political support (vote acquisition) to Maria FaniMasela significantly. 


\section{REFERENCES}

Bogdan \& Taylor. (2012). Prosedur Penelitian. In Moleong, Pendekatan Kualitatif. Jakarta: PT Rineka Cipta.

Firmanzah. (2012). Marketing Politik antara Pemahaman dan Realitas. Jakarta: Yayasan Obor Indonesia.

Fox, Richard L and Lawless, J. L. (2011). Gendered Perceptions and Political Candidacies: A Central Barrier to Women's Equality in Electoral Politics. American Journal of Political Science, 55(1), 59-73.

Kacung Marijan. (2010). Sistem Politik Indonesia: Konsolidasi Demokrasi Pasca Orde Baru. Jakarta: Kencana Prenada Media Group.

Laporan Panitia Pemilihan Kepala Desa Lauran Tahun 2014.

Miles, M. B., Huberman, A. M., \& Saldaña, J. (2014). Qualitative Data Analysis: A Methods Sourcebook. Retrieved from http://researchtalk.com/wp-content/uploads/2014/01/MilesHuberman-Saldana-Drawing-and-Verifying-Conclusions.pdf

Niffenegger, P. . (1989). Strategies for Success from the Political Marketers. The Journal of Consumer Marketing, 6(1), 45-51.

Peraturan Daerah Kabupaten Maluku Tenggara Barat Nomor 8 Tahun 2013 Tentang Tata Cara Pencalonan dan Pemilihan .

Peraturan Menteri Dalam Negeri Republik Indonesia Nomor 112 Tahun 2014 tentang Pemilihan Kepala Desa.

Reid, D. (1988). Marketing the Political Product. European Journal of Marketing, 22(9), 34-74.

Schroder, P. (2010). Strategi Politik. Jakarta: Friedrich Nauman Stiftung Fur die Freiheit, Indonesia. Sugiyono. (2012). Metode Penelitian Kuantitatif dan Kualitatif. Bandung: Alfhabeta.

Undang-Undang Republik Indonesia Nomor 32 Tahun 2004 Tentang Pemerintahan Daerah

Undang-Undang Republik Indonesia Nomor 6 Tahun 2014 Tentang Desa

Wring, D. (1996). Political Marketing and Party Development in Britain: A "Secret" History. European Journal of Marketing, 10(11), 100-111. 